\title{
Peer support for people with mental illness
}

\author{
Suporte interpares na doença mental
}

\author{
Filipa Alexandra lourenço Campos'1, Ana Rita Pinto de Sousa', Vânia Patrícia da Costa Rodrigues², António José Pereira da Silva \\ Marques ${ }^{1}$, Artemisa Agostinha Monteiro da Rocha Dores ${ }^{1}$, Cristina Maria Leite Queirós ${ }^{1}$

\begin{abstract}
'Laboratório de Reabilitação Psicossocial da Faculdade de Psicologia e de Ciências da Educação da Universidade do Porto/Escola Superior de Tecnologia da Saúde do Porto, Instituto Politécnico do Porto (FPCEUP/ESTSPIPP), Porto, Portugal.

${ }^{2}$ ESTSPIPP, Porto, Portugal.
\end{abstract}

Received: 4/22/2014 - Accepted: 5/8/2014

DOI: 10.1590/0101-60830000000009

\begin{abstract}
Background: Peer support is a mutual aid system based on the belief that someone who faced/overcome adversity can provide support, encouragement and guidance to those who experience similar situations. Objective: To conduct a systematic review that describes this concept and characterizes peer supporters, its practice and efficacy. Method: Research on ISI Web of Science, EBSCO Psychology and Behavioral Sciences Collection and Medline databases (from 2001 to December 2013) was conducted using as keywords "mental illness", "mental health", "psychiatric disability", "mental health services", combined with "peer support", "mutual support", "self-help groups", "consumers as providers", "peer-run services", "peer-run programs" and "social support". Results: We found 1,566 articles and the application of both the exclusion (studies with children, teenagers and elderly people; disease in comorbidity; peer support associated to physical illnesses or family members/caregivers) and the inclusion criteria (full text scientific papers, peer support or similar groups directed for schizophrenia, depression, bipolar or psychotic disorders) lead to 165 documents, where 22 were excluded due to repetition and 31 to incomplete text. We analyzed 112 documents, identifying as main peer support categories: characterization, peer supporter, practices and efficacy. Discussion: Despite an increasing interest about this topic, there is no consensus, suggesting realizing more studies.
\end{abstract}

Campos FAL, et al. / Rev Psiq Clín. 2014;41(2):49-55

Keywords: Peer support, mental disorders, personal recovery, systematic revision.

\section{Resumo}

Contexto: O suporte interpares é um sistema de ajuda mútua baseado na crença de que alguém que enfrentou/superou adversidades pode oferecer apoio, encorajamento e orientação a outros que enfrentam situações similares. Objetivo: Realizar uma revisão sistemática que caracterize o suporte interpares como prática, analise a sua eficácia e caracterize os pares prestadores de suporte interpares. Método: Pesquisa nas bases de dados ISI Web of Science, EBSCO Psychology and Behavioral Sciences Collection e Medline (2001 a dezembro de 2013), utilizando as palavras-chave "mental illness", "mental health", "psychiatric disability", "mental health services", combinadas com "peer support", "mutual support", "self-help groups", "consumers as providers", "peer-run services", "peer-run programs" e "social support". Resultados: Encontraram-se 1.566 artigos e foram aplicados os critérios de exclusão (artigos com crianças, adolescentes e idosos; doença mental em comorbidade; suporte interpares em doenças físicas ou familiares/cuidadores) e de inclusão (revistas científicas com texto integral disponível; suporte interpares ou grupos similares dirigidos a esquizofrenia, depressão, transtorno bipolar e outras perturbações psicóticas), resultando em 165 documentos. Excluíram-se 22 por repetição e 31 por texto incompleto, resultando em 112, os quais se identificaram como principais categorias do suporte interpares: caracterização, prestador de suporte, práticas e eficácia. Conclusão: Existe interesse crescente pelo tema, embora alguns domínios não sejam consensuais, sugerindo necessidade de mais estudos.

Campos FAL, et al. / Rev Psiq Clín. 2014;41(2):49-55

Palavras-chave: Suporte interpares, transtornos mentais, recuperação pessoal, revisão sistemática.

\section{Introduction}

Peer support is a system of mutual aid that is based on principles of respect, shared responsibility and empathic understanding of the other's situation. This understanding stems from a common experience of emotional and psychological suffering ${ }^{1-3}$, based on the belief that someone who has faced and overcome some sort of adversity can offer support, encouragement, hope and guidance to others who face similar situations ${ }^{2}$. Peer supporters have an empathetic understanding and can draw on shared experience when working with peers ${ }^{4}$.

This practice is not based on psychiatric or disease models or on diagnosis criteria that emphasize the person's symptoms and problems, but on models that value people's positive aspects of and their ability to function effectively in different contexts ${ }^{3}$. However, even though peer support is accepted and recognised in the treatment of many conditions (e.g. addictions, cancer...), the stigma and stereotypes associated with mental illness have led people who are at an advanced stage in their recovery process to refrain from offering their contribution to the mental health system ${ }^{2}$. Despite these barriers, peer support, which allows someone with an experience of mental illness to give and/or receive support from their peers, has been used and is becoming more and more a reality in the mental health system of several countries ${ }^{2,5-8}$.

The literature ${ }^{2}$ suggests that there are three broad categories of peer-delivered intervention: naturally occurring mutual support, participation in peer-run programmes and the use of mental health service users as providers of services and support. Mutual support is a process in which people get together voluntarily to help each other in dealing with common issues and share concerns. This is the most basic form of peer support and is provided by individuals on 
a one-to-one basis and in an informal setting 9 . In peer-run groups, activities are carried out in substitution or in addition to peer support ${ }^{2}$, and administration and support in these services is controlled and organised by patients, and stands as an alternative to the activities provided by traditional mental health services ${ }^{9}$. Both in mutual support or peer-run groups, relationships between peers must be reciprocal in nature. Although some peers may be seen as having more skills or experience than others, all participants are expected to benefit from this relationship. Lastly, with respect to peers as service providers, these are usually people with a history of mental illness who have experienced significant improvement in their psychiatric condition and, so, offer their services and/or support to others with severe mental disorders who are not yet at an advanced stage in their recovery process ${ }^{2}$. This type of peer support is considered a formal therapeutic intervention, characterised by an asymmetrical relationship, in which at least one of the parties provides a service/ support and the other is the beneficiary of that service/support ${ }^{2}$. In this type of service, people with experience of mental illness are trained and hired to provide support for other people who resort to the traditional health services. This is the definition most commonly used in mental health literature?

The effectiveness of peer support has been researched through formal interventions within health services embedded within the community ${ }^{10}$. Studies show the existence of multiple positive outcomes for people with mental illness ${ }^{6,10}$ and so, it plays an important role in the recovery of all stakeholders involved in this process $^{10,11}$. The positive effects can be grouped into three categories, depending on those who benefit from them: patients, service providers and the mental health system ${ }^{10}$. These programmes also provide a sense of connection, belonging and community, often lacking in individuals who only benefit from the services of the traditional mental health system ${ }^{12}$.

Despite these positive effects, peer support in mental illness is still a new and unexplored subject, which generates controversy and ambiguity. This study aims to conduct a systematic review of the scientific literature in this area and presenting a model that allows the description and systematisation of the factors that characterise peer support and their effectiveness over the last twelve years.

\section{Methods}

Between 2001 and December 2013, a systematic review of the literature was performed on the scientific papers indexed in the ISI Web of Science, EBSCO Psychology and Behavioural Sciences Collection and Medline with Full Text databases. The following keywords and Boolean language search equation were used: "mental illness" or "mental health" or "psychiatric disability" and "peer support" or "mutual support" or "self-help groups" or "consumer as providers" or "peer-run services" or "peer-run programs". In Medline the following Medical Subject Headings (MeSH) were used: "mental disorders" or "mental health" or "mental health services" and "selfhelp groups" or "social support" or "peer support". The terms were searched as "topics" in ISI, and in "all the fields" in EBSCO. The terms selected from this research stem from the knowledge of the literature in the field. No language restriction was applied.

Articles with children, adolescents and elderly people, studies of mental illness in comorbidity with other clinical situations and peer support applied to physical disorders and/or to family members/ caregivers were excluded. The studies included were those that met the following criteria: publication in scientific journals, full text available and peer support or similar groups focusing on mental illness (schizophrenia, depression, bipolar disorder and other psychotic disorders).

Titles and abstracts were reviewed by two of the authors to exclude irrelevant or ineligible papers. Each reviewer then analysed the full text of the remaining articles to decide on their eligibility. A third reviewer resolved discrepancies during a consensus discussion. A final group of eighty-two documents was obtained and analysed using NVivo 9.
The data analysis was performed by two independent investigators and validated by a third one (rater). The content analysis process, using the NVivo 9 consisted of a deductive analysis (with previous categories) whose categories and subcategories derived from the knowledge of literature in the field and translated the topics expressed in the reviewed literature. The developed model was applied to the coding of the material. The two researchers coded the material based on the hierarchy tree with the identified (sub)categories and both analysed the entire material. Record units considered were ideas (units of imprecise dimension but that allow the comprehension of the context, giving greater meaning to the record unit). The counting unit was the criteria of every time the unit (topic) appears. The coding was performed independently, thus seeking to test the robustness and the internal validity of the tool previously built. Peer agreement was calculated using Cohen's kappa (0.95), as it is considered a more robust measure than simple percentage. Cohen's kappa is a measure for assessing the reliability of categories, i.e., checking the percentage in which two researchers agree on a given number of items/categories. It is one of the most widely used measures of inter-rater agreement ${ }^{13}$.

\section{Results}

In total, 1,566 articles were identified and after the application of the inclusion and exclusion criteria, 165 papers remained, of which 22 were excluded due to repetition and 31 due to not including the full text. The remaining 112 documents were analysed in their entirety (Figure 1), and it was found that, despite some fluctuations,

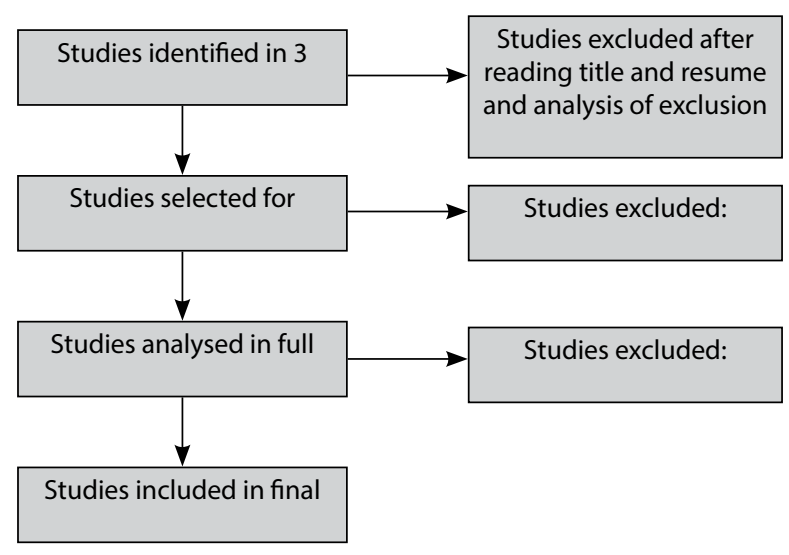

Figure 1. Flow chart showing effects of inclusionary and exclusionary criteria on final sample selection.

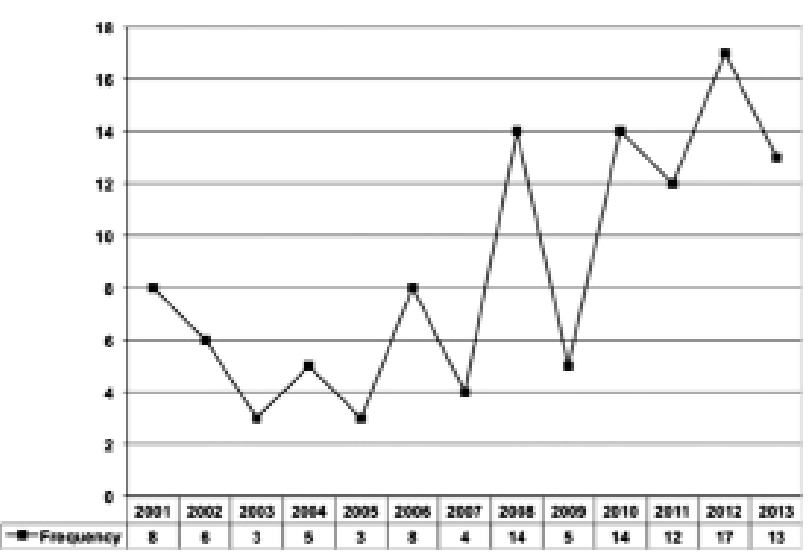

Figure 2. Number of publications in the previous twelve-year 
the number of publications that meet the criteria for this review has increased over the last years (Figure 2).

Nuclear primary and secondary order categories related to peer support should be highlighted: Characterisation (Definition, Types, Objectives and Target Population); Peer Supporter (Characteristics, Selection Process, Training and Supervision); Practices (Models, Local, Contact Phase and Programmes); and Efficacy (Empirical and Theoretical Studies). The several categories were broken down into the dimensions that emerged most frequently in the literature, in some cases, reaching seventh level variables (Table 1 to Table 4).

\section{Discussion}

Despite the variations, the growing number of publications that meet the criteria of this review reveals the current interest in peer support and its relevance as a research area. The literature review resulted in a better conceptual outlining of this practice and its contribution for the personal recovery of people with experience of mental illness, as well as in a more detailed knowledge of the main limitations associated with the studies and knowledge on the subject. Taking as a starting point the four major categories that emerged (characterisation, peer supporter, practices and effectiveness), with respect to characterisation, it was found that peer support interventions are used in a wide variety of mental illness pathologies, although it is still unusual to see those pathologies portrayed in specific studies.

As to the practices, the theory behind them is the area most explored in literature, and there is some consensus, in particular, as regards their definition and types. However, the models upon which this practice is based are mentioned only in a minority of those same studies $^{22,32,42,43,54}$. Similarly to what is observed in models, there is also a greater need for consensus regarding the goals of peer support, which, although becoming more and more associated with concepts like recovery and empowerment, are not yet fully defined. On the other hand, in relation to peer support programmes, it appears that, although it is advocated that they may be applicable in a variety of locations, the issues which they address, as well as the frequency and duration with which they take place, tend to vary from one organisation to another. The way these programmes are evaluated is also a gap in the knowledge concerning this topic.

With regard to the provider or peer providing the support, a consensus was found regarding the characteristics required, although its role within the organisations is still not completely defined, a fact that is pointed out in some studies as a barrier to the implementation of peer support ${ }^{47}$. The same was observed with respect to all procedures underlying the inclusion of peer supporters

Table 1. Results to category characterization

\begin{tabular}{|c|c|c|}
\hline Characterization & Results & Authors \\
\hline Definition & $\begin{array}{l}\text { Peer support definitions can be conceptualised into three main groups: } \\
\text { - a system for giving and receiving help based on the principles of respect, shared responsibility and } \\
\text { mutual aid } \\
\text { - emotional and instrumental support, mutually offered or provided to people with similar } \\
\text { experiences of mental illness, with the goal of producing the desired personal or social changes } \\
\text { - a system based on the belief that people who have faced and overcome adversity can offer useful } \\
\text { support, encouragement and hope to others who are in similar situations }\end{array}$ & 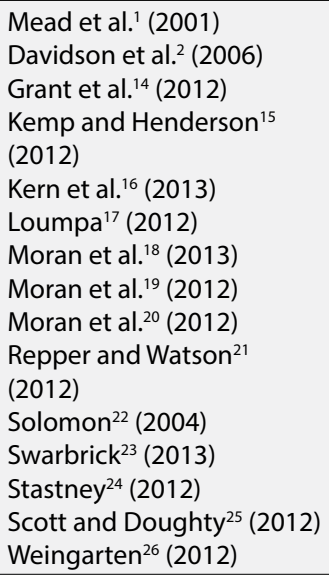 \\
\hline Types & $\begin{array}{l}\text { In literature there are different types of peer support: } \\
\text { - mutual help group } \\
\text { - on-line and phone support groups } \\
\text { - peer-provided services } \\
\text { - operationalization of peer-provided services/programmes } \\
\text { - peer partnerships } \\
\text { - employability of peer supporters in health services }\end{array}$ & $\begin{array}{l}\text { Davidson et al. }{ }^{2}(2006) \\
\text { Moran et al. }{ }^{18}(2013) \\
\text { Moran et al. }{ }^{19}(2012) \\
\text { Solomonon } 22(2004) \\
\text { Scott and Doughy }{ }^{25}(2012) \\
\text { Coniglio et al. } .^{27}(2012) \\
\text { DeAndrea and Anthony }{ }^{28} \\
(2013) \\
\text { Mancini et al. } .^{29}(2013) \\
\text { Rabenschlag et al. } .^{30}(2012) \\
\text { Walker and Bryant }^{31}(2013)\end{array}$ \\
\hline Objetives & $\begin{array}{l}\text { The objectives are mainly centred around the concepts of personal recovery, empowerment and } \\
\text { advocacy, seeking to improve social functioning in daily life activities, self-esteem and self-efficacy }\end{array}$ & $\begin{array}{l}\text { Brown et al. }^{32}(2008) \\
\text { Chinman et al. } .^{33}(2006) \\
\text { Corrigan et al. }{ }^{34}(2013) \\
\text { Fukui et al. }{ }^{35}(2010) \\
\text { Henderson and Kemp } \\
\text { (2013) } \\
\text { Hodges and Segal }{ }^{37}(2002) \\
\text { Ostrow and } \text { Adams }^{38}(2012)\end{array}$ \\
\hline
\end{tabular}


Table 2. Results to category peer supporter

\begin{tabular}{|c|c|c|}
\hline Peer supporter & Results & Authors \\
\hline Characteristics & $\begin{array}{l}\text { Information regarding the stage of the disease, the contractual relationship and the role of individuals } \\
\text { in organisations is structured as follows: } \\
\text { - Peer supporters must suffer from the same pathology as the target population, but they must be at } \\
\text { an advanced stage of the recovery process } \\
\text { - In the case of mutual help or self-help groups, peer providers work on a volunteer basis, without any } \\
\text { compensation } \\
\text { - In the remaining types of peer support, peer supporters employees, earning a monetary } \\
\text { remuneration } \\
\text { - There are also some organisations where volunteer work and employment of people with } \\
\text { experience of mental illness coexist } \\
\text { - The service rendering scheme is generally organised in part-time shifts } \\
\text { - The role of peer supporters is to promote group activities, provide support in daily life activities, } \\
\text { at work and in the community with their peers. They also assist their peers in making informed } \\
\text { decisions and developing new strategies for dealing with symptoms }\end{array}$ & $\begin{array}{l}\text { Davidson et al. }{ }^{2}(2006) \\
\text { Grant et al. } .^{14}(2012) \\
\text { Repper and Watson }{ }^{21} \\
(2012) \\
\text { Solomon }{ }^{22}(2004) \\
\text { Walker and Bryant }{ }^{31}(2013) \\
\text { Brown et al. }{ }^{32}(2008) \\
\text { Chinman et al. } .^{33}(2006) \\
\text { Chinman et al. } .^{41}(2001) \\
\text { Chinman et al. } .^{47}(2008) \\
\text { Hodges and Hardiman }{ }^{48} \\
(2006) \\
\text { Lawn et al. } .^{99}(2008) \\
\text { Moll et al. } .^{50}(2009) \\
\text { Nestor and Galletly }{ }^{51} \\
\text { (2008) }\end{array}$ \\
\hline $\begin{array}{l}\text { Selection } \\
\text { process }\end{array}$ & $\begin{array}{l}\text { Few references were found regarding the methods and procedures to adopt or the most valued } \\
\text { characteristics, and it is not clear who should be responsible for the selection process } \\
\text { References found value the following selection criteria for this role: } \\
\text { - personal experience with the pathology } \\
\text { - readiness to professional development } \\
\text { - good social and communication skills } \\
\text { - motivation to take on this role }\end{array}$ & $\begin{array}{l}\text { Franke et al. } .^{9}(2010) \\
\text { Repper and Watson }{ }^{21} \\
(2012) \\
\text { Lawn et al. } .^{99}(2008) \\
\text { Moll et al. } .^{50}(2009) \\
\text { Ahmed et al. }{ }^{52}(2013) \\
\text { Barber et al. } .^{53}(2008) \\
\text { Dennis }{ }^{54}(2003) \\
\text { Gillard et al. } .^{55}(2013) \\
\text { Simoni and Franks }{ }^{56}(2011) \\
\end{array}$ \\
\hline Training & $\begin{array}{l}\text { Training must be administered by health professionals and by more experienced peer supporters, } \\
\text { although it is not clear who should be in charge. } \\
\text { There is no consensual information on the methods, type and duration of the training, and we found } \\
\text { only one article that mentions a } 40 \text {-hour training programme. In general, relevance is given to topics } \\
\text { such as: } \\
\text { - dealing with/sharing one's experience with mental illness } \\
\text { - communication and group leadership skills } \\
\text { - the educational process regarding mental illness } \\
\text { - personal recovery, suicide prevention } \\
\text { - definition of the role of the peer supporter }\end{array}$ & $\begin{array}{l}\text { Franke et al. }{ }^{9}(2010) \\
\text { Bouchard et al. }{ }^{10}(2010) \\
\text { Grant et al. } .^{14}(2012) \\
\text { Kern et al. }{ }^{16}(2013) \\
\text { Repper and Watson }{ }^{21} \\
(2012) \\
\text { Weigarten }{ }^{26}(2012) \\
\text { Rabenschlag et al. } .^{30}(2012) \\
\text { Ostrow and Adams }{ }^{38}(2012) \\
\text { Chinman et al. } .^{41}(2001) \\
\text { Chinman et al. } .^{47}(2008) \\
\text { Lawn et al. } .^{9}(2008) \\
\text { Nestor and Galletly }{ }^{51} \\
(2008) \\
\text { Gillard et al. } .^{55}(2013) \\
\text { Cook et al. }{ }^{57}(2010) \\
\text { Fukkink }{ }^{58}(2011) \\
\text { Pickett et al. } . .^{59}(2010) \\
\text { Rabenschlag et al. } .^{60}(2012) \\
\text { Robinson et al. } .^{61}(2010) \\
\text { Swarbrick et al. }{ }^{62}(2009)\end{array}$ \\
\hline
\end{tabular}

in organisations (process of selection, training and supervision), and information on such procedures is almost non-existent.

Lastly, from the analysis conducted on the effectiveness of peer support, it was found that several authors argue that, despite the scarce evidence and the need for further studies ${ }^{3,72}$, this practice is generally considered as beneficial for customers, for peers providing the service and for the mental health system altogether ${ }^{40,44}$. It was also possible to observe that efficacy studies are mainly focused on the benefits for customers and that the results they report are similar to those obtained in traditional mental health services and even better when applied concurrently. Furthermore, it was concluded that there are more empirical than theoretical studies addressing this subject, and that the procedures, participants and instruments used in these studies vary, adjusting to the goals set by each author.

It should be noted that previous literature review studies on peer support exist ${ }^{3,44}$, although infrequent or focusing only on specific areas of this subject. In this work, the structural methodology is new in this area and, in addition, it analyses peer support in a comprehensive way, attempting to portray this reality in the factors that characterise the concept, the peer supporters, the practice, and also its effectiveness. There was, thus, an attempt to find answers on the use of peer support as a mental health service for those engaged in research or clinical practice in this area, through more systematised and updated information, aiming at contributing to the 
Table 3. Results to category practices

\begin{tabular}{|c|c|c|}
\hline Practices & Results & Authors \\
\hline Models & $\begin{array}{l}\text { The models most advocated are the following: } \\
\text { - Social support } \\
\text { - Experimental knowledge } \\
\text { - "Helper-therapy" principle } \\
\text { - Social learning theory } \\
\text { - Social comparison theory } \\
\text { - Empowerment theory } \\
\text { - Cognitive-behavioural therapy } \\
\text { - Socio-ecological model }\end{array}$ & 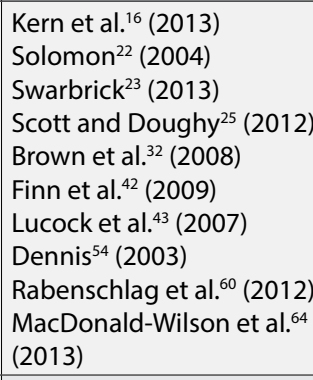 \\
\hline Local & $\begin{array}{l}\text { Peer support can take place in several contexts: } \\
\text { - In outpatient and inpatient hospital treatments } \\
\text { - In the community: at home, at school, in prisons and in primary care centres }\end{array}$ & 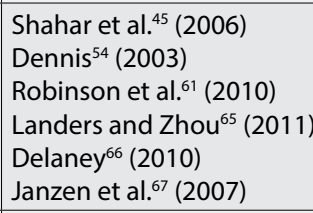 \\
\hline Contact Phase & $\begin{array}{l}\text { This is a relatively unexplored topic, although the authors who have studied it argue that the first } \\
\text { contact should occur early in the onset of the illness and still in inpatient treatment or immediately } \\
\text { after discharge }\end{array}$ & $\begin{array}{l}\text { Chinman et al. }{ }^{41}(2001) \\
\text { Lawn et al. }{ }^{49}(2008) \\
\text { Nestor and Galletly }{ }^{51} \\
(2008) \\
\text { Robinson et al. } .^{61}(2010)\end{array}$ \\
\hline
\end{tabular}

Table 4. Results to category efficacy

\begin{tabular}{|l|l|c|}
\hline Efficacy & Results & Authors \\
\hline
\end{tabular}

implementation of a model that appears to have benefits both for people with mental illness and for the services.

\section{Conclusion}

Peer support is a practice that can significantly contribute to the recovery of individuals with personal experience of mental illness, through support provided by other people who have experienced and overcome similar situations, by means of understanding, hope, and the sharing of strategies and guidelines. Apart from the role that the peer supporter can play in their own rehabilitation process and in that of its peers, this intervention will also improve the services provided by mental health organisations and possibly reduce costs for the very mental health system, by reducing the number of institutionalisations. The production of scientific evidence and the creation of more 
specific lines of research, which demonstrate effectiveness and generate guidelines for the development and implementation of peer support programmes, may facilitate the dissemination of this practice in other countries. The results obtained in this study clearly demonstrate that this is a promising field for further research, which explore the areas of the literature listed above.

\section{References}

1. Mead S, Hilton D, Curtis L. Peer support: a theoretical perspective. Psychiatr Rehabil J. 2001;25(2):134-41.

2. Davidson L, Chinman M, Sells D, Rowe M. Peer support among adults with serious mental illness: a report from the field. Schizophr Bull. 2006;32(3):443-50.

3. Repper J, Carter T. A review of the literature on peer support in mental health services. J Ment Health. 2011;20:392-411.

4. Cabral L, Strother H, Muhr K, Sefton L, Savageau J. Clarifying the role of the mental health peer specialist in Massachusetts, USA: Insights from peer specialists, supervisors and clients. Health Soc Care Community. 2014; 22(1):104-12.

5. Silva T, Lovisi G, Cavalcanti M, Dahl C, Conover S, Valencia E, et al. Intervenção para períodos críticos - Transferência de cuidados: uma nova intervenção psicossocial para indivíduos com transtornos mentais graves na América Latina. Rev Psiq Clín. 2013;40(6):243.

6. Simpson A, Quigley J, Henry SJ, Hall C. Evaluating the selection, training, and support of peer support workers in the United Kingdom. J Psychossocial Nurs. 2014;52(1):31-40.

7. Repper J. Peer supporter workers: theory and practice. United Kingdom; 2013. Available from: <http://www.nhsconfed.org/Documents/ImROC Peer Support Workers Theory and Practice.pdf $>$.

8. O'Hagan M, Cyr C, McKee H, Priest R. Making the case for peer support. Calgary: Mental Health Commission of Canada; 2010. p. 1-92.

9. Franke CCD, Paton BC, Gassner LA. Implementing mental health peer support: a South Australian experience. Aust J Prim Health. 2010;16(2):179-86.

10. Bouchard L, Montreuil M, Gros C. Peer support among inpatients in an adult mental health setting. Issues Ment Health Nurs. 2010;31(9):589-98.

11. Coatsworth-Puspoky R, Forchuk C, Ward-Griffin C. Peer support relationships: an unexplored interpersonal process in mental health. J Psychiatr Ment Health Nurs. 2006;13:490-7.

12. Schutt RK, Rogers ES. Empowerment and peer support: structure and process of self-help in a consumer-run center for individuals with mental illness. J Community Psychol. 2009;37(6):697-710.

13. Fonseca R, Silva P, Silva R. Acordo inter-juízes: o caso do coeficiente kappa. Laboratório Psicol. 2007;5(1):81-90.

14. Grant E, Reinhart C, Wituk S, Meissen G. An examination of the integration of certified peer specialists into community mental health centers. Community Ment Health J. 2012;48:447-81.

15. Kemp V, Henderson AR. Challenges faced by mental health peer support workers: peer support from the peer supporter's point of view. Psychiatr Rehabil J. 2012;35(4):337-40.

16. Kern S, Zarate R, Glynn M, Turner LR, Smith KM, Mitchel SS, et al. A demonstration project involving peers as providers of evidence-based, supported employment services. Psychiatr Rehabil J. 2013;36(2):99-107.

17. Loumpa V. Promoting recovery through peer support: possibilities for social work practice. Soc Work Health Care. 2012;51(1):53-65.

18. Moran S, Russinova Z, Gidugu V, Gagne C. Challenges experienced by paid peer providers in mental health recovery: a qualitative study. Community Ment Health J. 2013;49:281-91.

19. Moran G, Russinova Z, Gidugu V, Yim J, Sprague C. Benefits and mechanisms of recovery among peer providers with psychiatric illness. Qual Heal Res. 2012;22(3):304-19.

20. Moran G, Russinova Z, Stepas K. Toward understanding the impact of occupational characteristics on the recovery and process of peer providers. Psychiatr Rehabil J. 2012;35(5):376-80.

21. Repper J, Watson E. A year of peer support in Nottingham: lessons learned. J Ment Health Training Educ Pract. 2012;7(2):70-8.

22. Solomon P. Peer support/peer provided services underlying processes, benefits, and critical ingredients. Psychiatr Rehabil J. 2004;27(4):392401.
23. Swarbrick M. Wellness-oriented peer approaches: a key ingredient for integrated care. Psychiatr Serv. 2013;64(8):723-6.

24. Stastney P. Introducing peer support work in Latin American mental health services. Cad Saúde Coletiva. 2012;20(4):473-81.

25. Scott A, Doughty C. "Confronted with paperwork": information and documentation in peer support. J Ment Health. 2012;21(2):154-64.

26. Weingarten R. The development of peer support in Netherlands, Brazil, and Israel. Psychiatr Rehabil J. 2012;35(6):476-7.

27. Coniglio F, Hancock N, Ellis L. Peer support within clubhouse: a grounded theory study. Community Ment Health J. 2012;48:153-60.

28. DeAndrea D, Anthony J. Online peer support for mental health problems in United States: 2004-2010. Psychol Med. 2013;43:2277-88.

29. Mancini A, Linhorst M, Menditto A, Colemand J. Statewide implementation of recovery support groups for people with serious mental illness: a multidimensional evaluation. J Behav Health Serv Res. 2013;40(4):391-403.

30. Rabenschlag F, Schusterschitz C, Conca A, Knuf A, Needham I, Hoffmann $\mathrm{H}$. Influence of single peer interventions on the recovery attitude of persons with a psychiatric disability. Scand J Caring Sci. 2012;26:755-60.

31. Walker G, Bryant W. Peer support in adult mental health services: a metasynthesis of qualitative findings. Psychiatr Rehabil J. 2013;36(1):28-34

32. Brown LD, Shepherd MD, Merkle EC, Wituk SA, Meissen G. Understanding how participation in a consumer-run organization relates to recovery. Am J Community Psychol. 2008;42(1-2):167-78.

33. Chinman M, Young AS, Hassell J, Davidson L. Toward the implementation of mental health consumer provider services. J Behav Health Serv Res. 2006;33(2):176-95.

34. Corrigan PW, Sokol KA, Rüsch N. The impact of self-stigma and mutual help programs on the quality of life of people with serious mental illnesses. Community Ment Health J. 2013;49(1):1-6.

35. Fukui S, Davidson LJ, Holter MC, Rapp CA. Pathways to recovery (PTR): impact of peer-led group participation on mental health recovery outcomes. Psychiatr Rehabil J. 2010;34(1):42-8.

36. Henderson R, Kemp V. Australian consumer perceptions of peer support. Asia-Pacific Psychiatry. 2013;5:152-6.

37. Hodges JQ, Segal SP. Goal advancement among mental health self-help agency members. Psychiatr Rehabil J. 2002;26(1):78-85.

38. Ostrow L, Adamns N. Recovery in the USA: from politics to peer support. Int Rev Psychiatr. 2012;24(1):70-8.

39. Burns-Lynch B, Salzer MS. Adopting innovations: lessons learned from a peer-based hospital diversion program. Community Ment Health J. 2001;37(6):511-21.

40. Chinman M, Kloos B, O'Connell M, Davidson L. Service providers' views of psychiatric mutual support groups. J Community Psychol. 2002;30(4):349-66.

41. Chinman MJ, Weingarten R, Stayner D, Davidson L. Chronicity reconsidered: improving person-environment fit through a consumer-run service. Community Ment Health J. 2001;37(3):215-29.

42. Finn LD, Bishop BJ, Sparrow N. Capturing dynamic processes of change in GROW mutual help groups for mental health. Am J Community Psychol. 2009;44(3-4):302-15.

43. Lucock M, Barber R, Jones A, Lovell J. Service users' views of self-help strategies and research in the UK. J Ment Health. 2007;16(6):795-805.

44. Pistrang N, Barker C, Humphreys K. Mutual help groups for mental health problems: a review of effectiveness studies. Am J Community Psychol. 2008;42(1-2):110-21.

45. Shahar G, Kidd S, Styron TH, Davidson L. Consumer support and satisfaction with mental health services in severe mental illness: the moderating role of morale. J Soc Clin Psychol. 2006;25(9):945-62.

46. Yip K, Lee L, Law SO. Self-help groups in Hong Kong. Adm Policy Ment Health. 2004;31(4):351-60.

47. Chinman M, Lucksted A, Gresen R, Davis M, Losonczy M, Sussner B, et al. Early experiences of employing consumer-providers in the VA. Psychiatr Serv. 2008;59(11):1315-21

48. Hodges JQ, Hardiman ER. Promoting healthy organizational partnerships and collaboration between consumer-run and community mental health agencies. Adm Policy Ment Health. 2006;33(3):267-78.

49. Lawn S, Smith A, Hunter K. Mental health peer support for hospital avoidance and early discharge: an Australian example of consumer driven and operated service. J Ment Health. 2008;17(5):498-508. 
50. Moll S, Holmes J, Geronimo J, Sherman D. Work transitions for peer support providers in traditional mental health programs: unique challenges and opportunities. Work. 2009;33(4):449-58.

51. Nestor P, Galletly C. The employment of consumers in mental health services: politically correct tokenism or genuinely useful? Australas Psychiatry. 2008;16(5):344-7.

52. Ahmed O, Birgenheir D, Buckley F, Mabe A. A psychometric study of recovery among certified peer specialists. Psychiatry Res. 2013;209:72131.

53. Barber JA, Rosenheck RA, Armstrong M, Resnick SG. Monitoring the dissemination of peer support in the VA Healthcare System. Community Ment Health J. 2008;44(6):433-41.

54. Dennis CL. Peer support within a health care context: a concept analysis. Int J Nurs Stud. 2003;40(3):321-32.

55. Gillard G, Edwards C, Gibson L, Owen K, Wright C. Introducing peer worker roles into UK mental health service teams: a qualitative analysis of the organizational benefits and challenges. BMC Health Serv Res. 2013;13:188.

56. Simoni JM, Franks JC, Lehavot K, Yard SS. Peer interventions to promote health: conceptual considerations. Am J Orthopsychiatry. 2011;81(3):351-9.

57. Cook JA, Copeland ME, Corey L, Buffington E, Jonikas JA, Curtis LC, et al. Developing the evidence base for peer-led services: changes among participants following Wellness Recovery Action Planning (WRAP) education in two statewide initiatives. Psychiatr Rehabil J. 2010;34(2):113-20.

58. Fukkink R. Peer counseling in an online chat service: a content analysis of social support. Cyberpsychol Behav Soc Netw. 2011;14(4):247-51.

59. Pickett SA, Diehl S, Steigman PJ, Prater JD, Fox A, Cook JA. Early outcomes and lessons learned from a study of the Building Recovery of Individual Dreams and Goals through Education and Support (BRIDGES) program in Tennessee. Psychiatr Rehabil J. 2010;34(2):96-103.
60. Rabenschlag F, Hoffman H, Conca A, Schusterscitz. Who benefits from peer support in psychiatric institutions? Psychiat Quart. 2012;83:209-20.

61. Robinson J, Bruxner A, Harrigan S, Bendall S, Killackey E, Tonin V, et al. Study protocol: the development of a pilot study employing a randomised controlled design to investigate the feasibility and effects of a peer support program following discharge from a specialist first-episode psychosis treatment centre. BMC Psychiatry. 2010;10:37.

62. Swarbrick M, Schmidt LT, Pratt CW. Consumer-operated self-help centers. environment, empowerment, and satisfaction. J Psychosoc Nurs. 2009;47(7):41-7.

63. Chinman M, Shoai R, Cohen A. Using organizational change strategies to guide peer support technician implementation in the Veterans Administration. Psychiatr Rehabil J. 2010;33(4):269-77.

64. MacDonald-Wilson KL, Deegan PE, Hutchison SL, Parrotta N, Schuster JM. Integrating personal medicine into service delivery: empowering people in recovery. Psychiatr Rehabil J. 2013;36(4):258-63.

65. Landers GM, Zhou M. An analysis of relationships among peer support, psychiatric hospitalization, and crisis stabilization. Community Ment Health J. 2011;47(1):106-12.

66. Delaney G. The peer specialist movement: an interview with Gayle Bluebird (interview by Kathleen Delaney). Issues Ment Health Nurs. 2010;31:232-4.

67. Janzen R, Nelson G, Hausfather N, Ochocka J. Capturing system level activities and impacts of mental health consumer-run organizations. Am J Community Psychol. 2007;39(3-4):287-99.

68. Corrigan PW, Calabrese JD, Diwan SE, Keogh CB, Keck L, Mussey C. Some recovery processes in mutual-help groups for persons with mental illness; I: qualitative analysis of program materials and testimonies. Community Ment Health J. 2002;38(4):287-301.

69. Biegel E, Pernice-Duca F, Chang C, D'Angelo L. Correlates of peer support in a clubhouse setting. Community Ment Health J. 2013;49:249-59. 